Historia

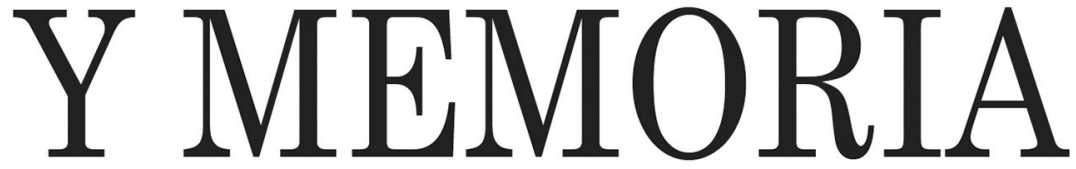

ISSN: 2027-5137 Julio - Diciembre, Año 2016 - Tunja, Colombia

\title{
Ilustración nariñense, la revista cultural del sur de Colombia 1924-1955
}

Maria Teresa Álvarez Hoyos

Páginas: 257 - 297 DOI: http://dx.doi.org/10.19053/20275137.5206

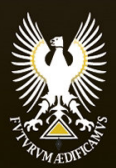




\title{
Ilustración nariñense, la revista cultural del sur de Colombia 1924-1955*
}

\author{
María Teresa Álvarez Hoyos ${ }^{1}$ \\ Universidad de Nariño - Colombia
}

Recepción: 02/04/2016

Evaluación: 29/04/2016

Aprobación: 25/05/2016

Artículo de Investigación e Innovación.

DOI: http://dx.doi.org/10.19053/20275137.5206

\section{Resumen}

Este artículo presenta la revista Ilustración Nariñense, una revista cultural de la primera mitad del siglo XX, que se editó en Pasto durante más de tres décadas, cumpliendo una importante función en la construcción de un imaginario colectivo sobre el progreso de la región que pasaba por lograr formas para superar el aislamiento geográfico. Como empeño editorial se convirtió en instrumento para cimentar un proyecto común de transformación de la región, a través de la lucha por la instalación de un sistema vial que facilitara las

* El trabajo se deriva del proyecto de investigación «Imaginarios de nación y construcción de la memoria regional en las publicaciones periódicas del sur de Colombia, 1930-1954», auspiciado por la Universidad de Nariño durante el año sabático de la autora. Año 2010.

1 Doctora en Ciencias de la Educación por la Red de Universidades Colombianas, RUDECOLOMBIA, UPTC. Magíster en Educación por la Universidad de Antioquia, Lic. Consejería Psicológica por la Universidad del Valle. Publicaciones recientes: 2015 «Acción Católica, Falange Española y República Liberal: su incidencia en la educación de las mujeres en Colombia. Años treinta». En Historia de las mujeres en Nariño. Tomo I. Pasto: Academia Nariñense de Historia, 307-328. ISBN: 9789585815049. 2015 «Plinio Enríquez, a la vanguardia de su generación». En Manual Historia de Pasto. Tomo XVI. Pasto: Academia Nariñense de Historia, 199-232. ISBN (Colección): 958-33-3584-3. Líneas de Investigación: Historia de la cultura intelectual, historia de la educación, historia regional. Correo electrónico: marialvarez540@hotmail.com 
comunicaciones con el país y el extranjero, bajo el supuesto de que el progreso de la región estaba anclado a la construcción de la vía férrea.

La actividad periodística y ensayística de la revista intentó quebrar el aislamiento intelectual de la comarca y propiciar la difusión de los intereses y problemas regionales. Para el estudio de la publicación se examinaron aspectos materiales y de contenido, que implicó la elaboración de índices temáticos y cronológicos y un análisis de los artículos de tipo hermenéutico, de tal modo que permitiera interpretar los ejes que estructuraron la revista.

Palabras clave: revista cultural, periodismo, región, Ferrocarril del Pacífico, escritores y lectores, Departamento de Nariño.

\title{
Ilustración Nariñense [Nariñense Illustration], the cultural magazine of the Colombian south 1924-1955
}

\begin{abstract}
This article presents Ilustración Nariñense [Nariñense Illustration], a cultural magazine of the first half of the XX c., edited in Pasto for more than three decades. This publication achieved an important role in the construction of a collective imaginary about the progress of the region, and its attempt to overcome geographic isolation. The editorial aim of this publication was to become an instrument for the establishment of a common project for regional transformation, through the struggle to install a transport system, that enabled communication with the interior of the country as well as with other countries; under the assumption that the progress of the region was linked to the construction of a railroad.
\end{abstract}

The magazine's journalistic work and essays attempted to break with the intellectual isolation of the area, and to promote the circulation of regional interests and problems. Material and content aspects were examined for the study of this publication. This implied the construction of thematic 
and chronological indexes, as well as a hermeneutic analysis of its articles, allowing for the interpretation of the axes that structured the magazine.

Key words: cultural magazine, journalism, región, Ferrocarril del Pacifico [Pacific Railroad], writers and readers, Department of Nariño.

\section{Ilustración Nariñense, la revue culturelle du sud de la Colombie, 1924-1955}

\section{Résumé}

Cet article présente l'Ilustración Nariñense, revue culturelle de la première moitié du $\mathrm{XX}^{\mathrm{e}}$ siècle, publiée à Pasto pendant plus de trois décennies. Elle a eu un grand succès dans la construction d'un imaginaire de progrès de la région, dont la consolidation exigeait le dépassement de l'isolement géographique. La revue est devenue l'instrument d'un projet de transformation de la région, en insistant sur la nécessité de construire un réseau routier pour accélérer les communications avec le pays et avec l'étranger, en considérant que le progrès régional dépendait de la construction de la voie ferrée.

La revue a essayé de rompre l'isolement intellectuel et de répandre l'intérêt pour les problèmes régionaux. Pour ce faire, nous avons examiné la matérialité et le contenu de la revue, ce qui a impliqué l'élaboration des catalogues thématiques et chronologiques dans une perspective herméneutique qui permet l'interprétation des axes qui ont structuré la revue.

Mots-clés: revue culturelle, journalisme, région, Chemin de fer du Pacifique, auteurs et lecteurs, Département de Nariño.

\section{Introducción}

El estudio sobre la revista Ilustración Nariñense como instrumento cultural, surgió a partir de la investigación "Imaginarios de nación y construcción de la memoria regional 
en las publicaciones periódicas del sur de Colombia, 19301954", la cual se propuso "re-conocer" el pasado de la región y de la localidad, a través de los escritos periodísticos que, como en el caso especial de Ilustración, aportaban una serie de claves sobre los procesos como se representó y fomentó la identidad regional y nacional.

En el caso analizado, se trata de una publicación que nos conecta con las principales problemáticas en que estaba inmersa la región, tanto en lo relativo a las modernizaciones que la élite dirigente quería introducir - ferrocarril, carreteras, urbanización, instituciones educativas - como en las discusiones en el campo intelectual, principalmente relacionadas con los aspectos históricos y literarios, cumpliendo una función aglutinante dentro del campo intelectual, lo que la convierte en referencia obligada de la historia de las ideas y de la cultura en el sur de Colombia ${ }^{2}$

En términos metodológicos, se realizó un trabajo de lectura y clasificación de los artículos de la revista por áreas temáticas, identificando las permanencias, las trayectorias de los temas, los temas principales y secundarios, procurando interpretar los contenidos tanto en el sentido manifiesto como latente.

Como revista cultural, Ilustración cubrió una gran variedad temática, aunque mantuvo un eje directriz en torno al tema de las obras de progreso para el Departamento de Nariño. Por sus características, se constituye en documento de gran riqueza para el estudio de las redes de intelectuales del sur de Colombia y de su articulación con las de nivel nacional. De acuerdo con la noción de Beatriz Sarlo acerca de las revistas como "laboratorios ideológicos, estéticos y de escritura", se puede decir que Ilustración fue para la región

2 Fernanda Beigel, «Las revistas culturales como documentos de la historia latinoamericana", Utopía y Praxis latinoamericana 8, n 20 (2003): 106, acceso el 22 de octubre de 2015, https://www.academia.edu/6342158/Las_revistas_culturales_ como_documentos_de_la_historia_latinoamericana_Fernanda_Beigel_

3 Beatriz Sarlo et al., «El rol de las revistas culturales», Espacios de Crítica y Producción, 12. Citado en Alexandra Pita González y María del Carmen Grillo, «Una 
el órgano de expresión de las propuestas políticas y artísticas de los grupos dirigentes.

Ilustración se propuso ser un "vocero civilizador"4, un agente impulsor de aquellos aspectos que llevaran a la población a cimentar mejores formas de hacer y convivir, de tal modo que pudiera lograr "el progreso moral y material de esta sección de la patria colombiana"; el vínculo con la región al amoldarse al temperamento peculiar de la sociedad nariñense, le garantizaría contar con muchos lectores y el apoyo material de los anunciantes, dos condiciones necesarias para consolidar su existencia.

En el texto se analiza el proyecto editorial con los propósitos originarios y la visión que le imprimió el director, el papel del editor -director- propietario, los escritores y las temáticas, el papel de la publicación en la creación de región y sus intentos por quebrar el aislamiento intelectual de la comarca $^{5}$ y los intercambios con los lectores a través de los correos, concursos y canjes.

propuesta de análisis para el estudio de revistas culturales», Revista Latinoamericana de Metodología de las Ciencias Sociales 5, $\mathrm{n}^{\circ} 1$ (2015), acceso el $1^{\circ}$ de noviembre de 2015, http://www.relmecs.fahce.unlp.edu.ar/article/view/relmecsv05n01a06

4 Denominación utilizada por Acevedo y Correa para referirse a uno de los sentidos de la función periodística, tal como lo asumieron periódicos como $E l$ Diario y Vanguardia Liberal: «autodefinirse cada uno agentes impulsores y a la vez parámetros de medida del nivel civilizatorio en sus respectivas sociedades». Álvaro Acevedo Tarazona y John Jaime Correa Ramírez, «Empresa, civilización y política: representaciones sobre el oficio periodístico en El Diario de Pereira y Vanguardia Liberal de Bucaramanga durante la República Liberal», Revista de Historia Regional y Local HistoReLo 5, no 9 (2013): 220-221, acceso el 3 de abril de 2016, http://www. revistas.unal.edu.co/index.php/historelo/article/view/36607

5 Los grupos sociales que componían el Departamento de Nariño, anteriormente denominado Provincia de Pasto, luchaban por realizar acciones que los reafirmaran como «civilizados» y, como anota Alexander Betancourt respecto a la noción de «frontera interior», destacaban el carácter «útil, rico y bello de ese espacio que desde el centro del Estado Nacional se ve lejano, vacío y salvaje». A. Betancourt, «Región y Nación: dos escalas sobre un tema de estudio», Relaciones (Zamora) 33, nº 130 (2012): 33, acceso el 20 de marzo de 2016, http://www.scielo.org.mx/scielo.php?script=sci_art text\&pid=S0185-39292012000200003 


\section{El Proyecto Editorial}

La revista Ilustración Nariñense, publicación mensual que se editó en Pasto entre los años 1924 y $1955^{6}$, corresponde a la denominación de revista cultural ${ }^{7}$ que caracterizó muchas de las publicaciones de las primeras décadas del siglo XX. Este proyecto editorial lo llevó a cabo Rafael Delgado Chaves durante más de 30 años $^{8}$, y fue una de las manifestaciones de la utilización del sistema medial que más contribuyó a perfilar la imagen de Pasto y de Nariño y a formar su propia memoria.

\section{Entre los ideales explicitados por la Revista se encontraban:}

Favorecer la obra de la educación, la industria, el comercio, la agricultura del Departamento, la higiene popular y hacer la propaganda más allá de los lares del terruño, de todo aquello que pueda granjearnos el aprecio de los que nos desconocen. Colocada en este ambiente y amoldada al temperamento peculiar de nuestra sociedad, espera ser favorecida de numerosos lectores y de buen acopio de anuncios que le aseguren una vida verdaderamente efectiva (...)

Abrigamos la firme esperanza, de que Ilustración Nariñense, a semejanza de otras revistas que circulan en regiones que disfrutan de más renombre de progreso y cultura que la

$6 \quad$ Se editaron 120 números entre 1924 y 1955. El n $^{\circ} 1^{\circ}$ se publicó el 24 de noviembre de 1924 y el 120 en julio de 1955, último número preparado por el director Rafael Delgado, quien falleció el 30 de septiembre de 1955.

7 Para Fernanda Beigel, las revistas culturales «constituyen un documento histórico de peculiar interés para una historia de la cultura, especialmente porque estos textos colectivos fueron un vehículo importante para la formación de instancias culturales que favorecieron la profesionalización de la literatura». Beigel, "Las revistas culturales", 111-112.

8 Jorge Orlando Melo, a propósito de los periódicos de comienzos del siglo XX, comenta que estos, «creados sin muchos recursos económicos, se consolidaron rápidamente como empresas familiares, que no recurrían a capitales externos», siendo la estructura empresarial familiar junto a otros rasgos como la fidelidad política, la objetividad, la independencia y el cubrimiento informativo aceptable lo que ha asegurado la permanencia de diarios como El Tiempo, El Espectador o El Colombiano. J. O. Melo, «La libertad de prensa en Colombia: pasado y perspectivas actuales», en Fortalezas de Colombia, ed. Fernando Cepeda Ulloa (Bogotá: Ariel y Banco Interamericano de Desarrollo, 2004). En cuanto a Ilustración Nariñense, Delgado la sostuvo como una empresa personal, con la que llevó a cabo campañas de índole netamente regional, proyecto que finalizó con su fallecimiento. 
nuestra, no cejará en la noble empresa que se propone de aportar su contingente para el progreso moral y material de esta sección de la patria colombiana. Expresado el ideal que se propone conseguir esta publicación, ofrece sus páginas a los intelectuales del Departamento que quieran colaborar con escritos de interés general, que versen sobre los tópicos indicados.

Para que Ilustración Nariñense tenga su atractivo especial, se la engalanará con el mayor número de fotograbados que le sea posible realizar, tomados de nuestra bella ciudad y de sus pintorescos alrededores, así como también de las demás poblaciones y campos de Nariño que merezcan publicarse ${ }^{9}$.

Fue un empeño editorial de largo aliento, que sirvió de ventana de expresión para quienes se estrenaban como escritores desde el campo del periodismo, y aportó abundantes elementos para construir el relato que uniría a los nariñenses entre sí y con el país. Martín Barbero en el texto "Colombia: ausencia de relato y desubicaciones de lo nacional" cita a Pécaut cuando afirmaba que "lo que le falta a Colombia más que un 'mito fundacional' es un relato nacional", refiriéndose a un relato que posibilitara a los colombianos de todas las clases, razas, etnias y regiones, ubicar sus experiencias cotidianas en una mínima trama compartida de duelos y de $\operatorname{logros}{ }^{10}$.

$\mathrm{Y}$ es justamente lo que se aprecia al analizar los ejemplares de Ilustración Nariñense, cuyos relatos empiezan a "tejer una memoria común, que como toda memoria social y cultural será siempre una memoria conflictiva pero anudadora" 1 . Este "texto colectivo" nos aporta luces sobre las formas como un grupo de intelectuales, de procedencias políticas y culturales diversas, interpretaron el proyecto común de transformación de la región con caracteres modernizadores

9 Rafael Delgado, «Nuestro Ideal», Ilustración Nariñense, n 1 (1924): 1.

10 Jesús Martín Barbero, «Colombia: ausencia de relato y desubicaciones de lo nacional», en Imaginarios de nación. Pensar en medio de la tormenta, coord. Jesús Martín Barbero (Bogotá: Ministerio de Cultura, Cuadernos de Nación, 2001), 17.

11 Martín Barbero, «Colombia: ausencia de relato», 17. 
y cómo esta revista, incidió en la "conformación/ampliación/ innovación del campo cultural o literario"12.

Desde el siglo XIX, la escritura de la historia local y regional no era preocupación para las élites del centro del país, ya que los referentes principales en torno a los cuales debería girar la escritura de la historia eran las categorías Estado y nación, de modo que las provincias "a pesar de ser partes básicas de la unidad nacional" solo se incorporaban a tales relatos si en aquéllas se hubiera dado algún suceso importante para la vida republicana o si allí habían surgido líderes políticos o militares ${ }^{13}$. Sin embargo, esta publicación tuvo un papel protagónico en el campo cultural regional y, tal como anota Maryluz Vallejo acerca de la prensa regional, esta "ha demostrado su capacidad de fijar rasgos de identidad, de representar la cultura, la mentalidad y el carácter de una comunidad; de divulgar hablas y costumbres que son de automático recibo por parte de sus lectores"14.

El vínculo con los lectores se vio reforzado tanto por el impulso que dio la revista a las causas ciudadanas como por los escritos de aquellos que eran considerados "valores de la región". Jorge Verdugo anota que el poeta Luis Felipe de la Rosa ${ }^{15}$ consideraba que "la colección de esta revista contenía la historia de Pasto y del Departamento en los últimos 20 años y que era la expresión auténtica de nuestra cultura vernácula"16.

$\mathrm{Su}$ director-propietario mantuvo una clara defensa de la religión católica y del partido conservador, sin evidenciar sectarismo hacia el partido liberal. La visión de país y de región que tenía Delgado y compartía con algunos de los

12 Beigel, «Las revistas culturales», 112.

13 Betancourt, «Región y Nación», 26-27.

14 Maryluz Vallejo Mejía, "Los genes de la prensa nonagenaria y centenaria», en Un papel a toda prueba. 223 años de prensa diaria en Colombia. (Bogotá: Andiarios, Biblioteca Luis Ángel Arango, 2012) acceso el 22 de marzo de 2016, http://www. banrepcultural.org/un-papel-a-toda-prueba/los-genes-de-la-prensa

15 Poeta nariñense (1878-1946).

16 Jorge Verdugo, Sobre el Canon y la Canonización de la Narrativa en Nariño en el siglo XX (Pasto: Editorial Universidad de Nariño, 2004), 47. 
colaboradores, se percibe poco permeable a los cambios ideológicos que se produjeron en las décadas del treinta y del cuarenta, cuando la hegemonía conservadora se vio sacudida por la llegada del liberalismo al poder, lo que dio lugar a reformas trascendentales en el orden social y político del país.

Esto no obsta para que la revista fuera un reflejo de importantes preocupaciones con respecto al desarrollo de la comarca, de su posición frente al país, tan menoscabada tradicionalmente; así como también, de la posibilidad de agitar y plantear el descontento de la población por el tratamiento de que eran objeto por parte de los diferentes gobiernos de la primera mitad del siglo XX. En contraste con lo expresado por los intelectuales nariñenses, los estudios sobre el pasado regional que elaboraron los grupos letrados antioqueños desde el siglo XIX, enfatizaron especialmente en diferenciar a Antioquia con el resto del país, mediante "la construcción de un discurso de identificación local"; dichos grupos "interpretaban las montañas que aislaban el territorio regional como las propiciadoras de las condiciones que permitieron el surgimiento de "los sobrios y enérgicos antioqueños" y la generación de un carácter independiente y democrático" ${ }^{17}$.

La revista impulsó y se vio impulsada por el proceso de urbanización de la ciudad y por los afanes modernizadores que incorporarían un factor de progreso como el ferrocarril, que despejaría zonas social y geográficamente aisladas, para que esta región tuviera condiciones de vida similares a las del centro del país. Esta mezcla de tradición y modernidad articuló las transformaciones sociales y culturales que tímida o abiertamente plantearon los escritores de la revista. Se trató de mantener la visión de un cambio gradual que no alterara los principios impuestos desde la visión católica-conservadora.

Plinio Enríquez, tal vez el escritor liberal con pensamiento más radical de quienes colaboraron en la revista, planteó en

17 Betancourt, «Región y Nación», 52-53. 
1935 la necesidad de que Ilustración Nariñense se abriera a los nuevos planteamientos propuestos por la República Liberal:

Para no referirme sino a las revistas nariñenses cito con especial agrado Anales de la Universidad, Boletín de Estudios Históricos e Ilustración Nariñense. (...) me he interesado en hacerles conocer por las grandes capitales que he recorrido, buscándoles canjes, haciendo reproducir artículos, a fin de que nuestros nuevos valores líricos y científicos sean plenamente conocidos fuera del terruño (...) Me encantaría que Ilustración, como exponente seccional de Nariño informe y analice serenamente la nueva etapa sociológica que se abre con el advenimiento de lo que en Colombia se conoce con el nombre de República Liberal ${ }^{18}$.

Menos aún se puede hablar de que la Revista tuviera contacto con el movimiento de las vanguardias latinoamericanas, corriente que tuvo su apogeo entre 1915 y 1940, y que se caracterizó por "la oposición a los valores del pasado y a los cánones artísticos establecidos por la burguesía del siglo XIX y comienzos del XX" ${ }^{19}$, así como también, por el rechazo a las circunstancias sociales generadas por el capitalismo $^{20}$.

Posibilitó la expresión de los intelectuales nariñenses, quienes escribieron sobre historia, educación, personajes de la región y todo tipo de eventos, ya fuera de orden religioso católico-, político, social, transporte o de higiene, que pudiera apoyar los ideales con los cuales fue diseñada la revista. En la mayoría de los números, Delgado o alguien de su equipo escribió sobre lo que consideraba el eje del desarrollo de Nariño -el Ferrocarril del Pacífico y todo lo que girara a su alrededor-, con el mensaje de que el progreso del Departamento estaba anclado a la construcción de la vía férrea.

18 Juan del Campo, «Breve entrevista con Plinio Enríquez», Ilustración Nariñense (1935): 27.

19 Jorge Schwartz, Las vanguardias latinoamericanas. Textos programáticos y críticos (México: FCE, 2002), 42.

20 José Alberto de la Fuente, "Vanguardias literarias ¿una estética que nos sigue interpelando?» Literatura y Lingüística, $\mathrm{n}^{\circ} 16$ (2005): 31-50, acceso el 14 de abril de 2015, http://www.scielo.cl/scielo.php?pid=S0716-58112005000100003\&script=sci_ arttext 


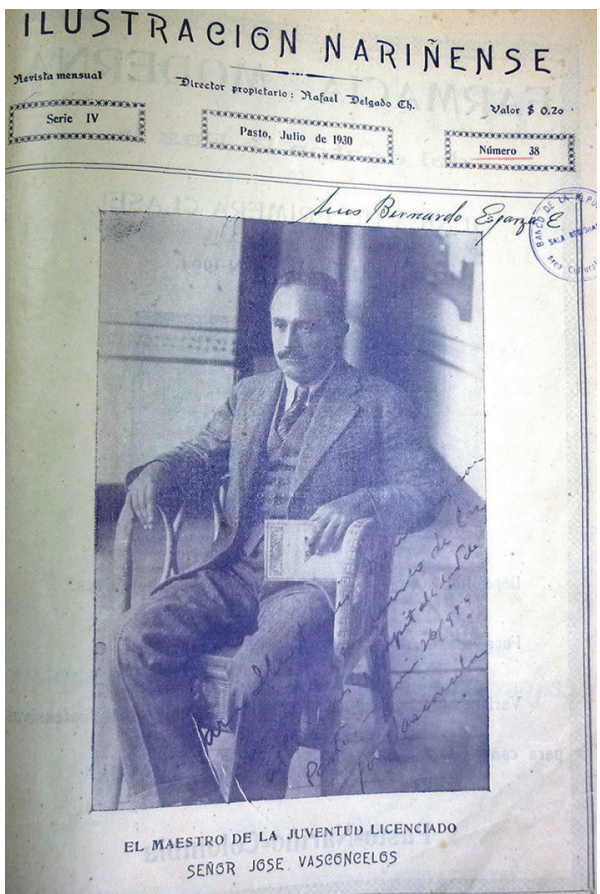

Imagen 1. "El Maestro de la Juventud Licenciado José Vasconcelos" Fuente: Portada Ilustración Nariñense nº 38 Julio 1930

Con el fin de que el "proyecto colectivo" de Nariño tuviera resonancia en las esferas del poder dio cabida a personajes de la política y la cultura como Luis López de Mesa, Luis Eduardo Nieto Calderón, Laureano Gómez o Eduardo Santos.

Al llegar a la edición No. 50 en el año 1933, su director, Rafael Delgado registraba algunos juicios críticos sobre la labor periodística y felicitaciones recibidas desde las primeras ediciones:

Cada edición de esta revista es un triunfo. Los suscriptores la esperan con ansia y la leen con delicioso placer. Su prestigio ha salvado los lindes patrios y en el exterior los hombres de letras le rinden pleitesía. El doctor Oscar Terán en Motivos Colombianos [Panamá] dice: «Ni por el formato, ni por la nitidez, ni por los fotograbados, ni por el material de lectura nada puede envidiar a las demás publicaciones de su género en el país. Es religiosa, histórica, política, comercial, económica, literaria y social y en todas estas actividades 
descuella selecta, limpia. Desfilan por sus páginas en efigies y biografías los hombres públicos del Departamento, las dignidades eclesiásticas, escogidos ejemplares de la mujer nariñense; todo aquello en fin, que piensa, escribe, moraliza y embellece, esto es, la vida entera; una vida fuerte activa, deseosa de mejorar»

\section{Juan Hienard ${ }^{21}$}

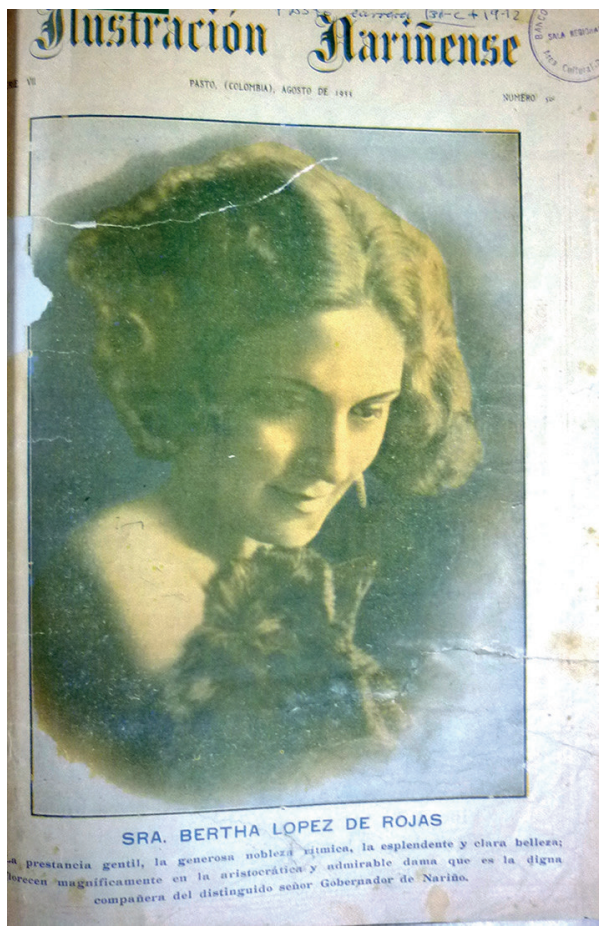

Imagen 2. Sra. Bertha López de Rojas.

Fuente: Portada Ilustración Nariñense n 50 Agosto 1933.

La propagandaincluida anunciaba las casasimportadoras y exportadoras de ciudades como Pasto, Túquerres, Tumaco y Barbacoas, con un despliegue de artículos que iban desde automóviles, máquinas de escribir, pianos, pianolas y artículos para el vestuario hasta delicados productos alimenticios, poniendo de manifiesto la comunicación que

21 Juan Hienard, «Nuestra Revista en Panamá», Ilustración Nariñense, n 51 (1933). 
tenía el Departamento con el mundo exterior ${ }^{22}$. La portada de la revista era elaborada en los talleres de fotograbado del Departamento y, posteriormente, en la casa fotográfica de propiedad del director de la publicación.

\section{El director - propietario Rafael Delgado Chaves (1884- 1955)}

Rafael Delgado nació en Pasto el 3 de abril de 1884, de la familia formada por Leonidas Delgado Flores y Carmen Chaves; a temprana edad ingresó a la Comunidad Marista y ejerció la docencia en Popayán, Buga e Ibagué en colegios de esta comunidad. A su regreso a Pasto, continuó las actividades docentes en la Escuela Normal y la Universidad de Nariño en las asignaturas de geometría, dibujo y francés ${ }^{23}$. Ejerció la fotografía como actividad profesional, y ofertaba sus servicios en la Revista en tres ramos: fotograbado, fotografía y ampliaciones.

En la segunda gobernación de Julián Bucheli (19181922), la Imprenta Departamental importó de Alemania un taller de fotograbado, gracias a las gestiones del director Enrique Zarama, quien "con espíritu progresista se esforzó por dotar a la imprenta de un taller de artes gráficas que sirviera para ilustrar las publicaciones oficiales y para atender también a trabajos particulares. El costo del taller fue de 4.000 pesos y contaba con todos los elementos para la ejecución de clises

22 Vallejo al respecto anota: «Desde la segunda década del siglo XX, El Tiempo y

El Espectador empezaron a competir en sus primeras páginas con avisos dirigidos a un público pudiente: automóviles Cadillac, compañías aseguradoras y de navegación fluvial, casas de modas, sombrererías y electrodomésticos importados de Estados Unidos. La publicidad, prueba reina del fortalecimiento de la industria y de los nuevos hábitos y consumos de la época, representó una segura fuente de ingresos para la prensa. Según Jaime Jaramillo Uribe, 'la introducción de la propaganda comercial es, a mi modo de ver, el aspecto esencial e innovador que moderniza el concepto de periodismo y de prensa en Colombia'» Maryluz Vallejo Mejía, "Los genes de la prensa nonagenaria»".

23 Edgar Ricardo Figueroa Santacruz, «La Fotografía en Pasto» Primera Parte, en Manual Historia de Pasto Tomo XVI (Pasto: Academia Nariñense de Historia, 2015), 144. 
de medio tono, zincografía y tricromía" ${ }^{24}$. Una vez instalado el taller, se hacía necesario contratar un técnico para su manejo, por lo cual la gobernación hizo gestiones en Bogotá, Quito y otros centros sin lograr conseguirlo y contactó a Rafael Delgado Chaves, quien aparece en la imagen $n^{\circ} 3$.

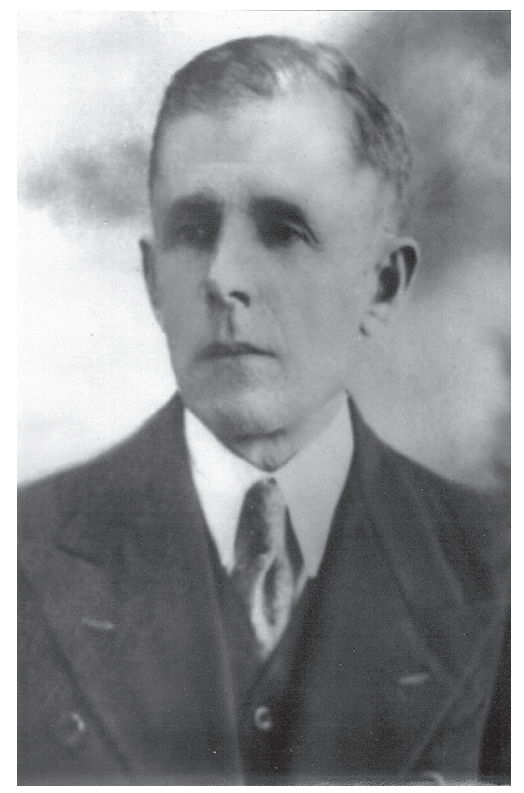

Imagen 3. Rafael Delgado Chaves.

Foto Archivo particular Sra. María Eugenia G. de Moncayo.

Fuente: Edgar Ricardo Figueroa, "La Fotografía en Pasto", 144.

Fue entonces, cuando se presentó un español, José Jordá, con quien la gobernación celebró contrato para dirigir el taller y enseñar a tres técnicos en artes gráficas, uno de los cuales fue Rafael Delgado. "Como el taller de fotografía fue desde el comienzo una novedad, se presentaron muchos trabajos para ilustrar periódicos y revistas. El Diario del Sur abrió un concurso de belleza en aquella época y con ese motivo hizo trabajar multitud de clisés con las candidatas al reinado. Todo esto sirvió para ejercitar a los alumnos en el manejo de las maquinarias y sustancias" ${ }^{25}$. Cuando don José Jordá se separó

24 Rafael Delgado, «Historia del taller de fotograbado de la Imprenta Departamental», Ilustración Nariñense, $\mathrm{n}^{\circ} 67$ (1938): 25.

25 Delgado, «Historia del taller», 25. 
del taller por haber cumplido su contrato quedó Delgado como director del Taller.

El señor Delgado, al igual que todos los directores de revistas, tuvo un papel de indiscutible valor al lograr que esta publicación se mantuviera vigente durante más de treinta años. Temístocles Pérez, uno de los más asiduos colaboradores de Ilustración Nariñense, decía que sostuvo la revista "contra viento y marea" 26 .

Sobre los directores de revistas, Fernanda Beigel anota:

Por lo general, constituyeron exponentes de alto calibre en el campo intelectual de cada país y actuaron como catalizadores de nuevos proyectos político-culturales, algunas veces fueron orientadores, otras veces contribuyeron como colaboradores, pero esencialmente fueron agentes de difusión por excelencia. Los directores de revistas fueron por lo general, editorialistas, dirigentes políticos, ensayistas, conferencistas, ideólogos, libreros, distribuidores, tipógrafos e imprenteros ${ }^{27}$.

El director de Ilustración reunió varias de las actividades enumeradas por Beigel ya que, además de redactar artículos de fondo de la publicación, escribía ensayos, era tipógrafo y se dedicaba a la fotografía, como lo atestiguan diversos anuncios que aparecían en las páginas interiores de la revista ${ }^{28}$.

Respecto a la figura del editor, Roger Chartier expresa que "todas las dimensiones de la historia de la cultura impresa pueden asociarse a la figura del editor, a la práctica de la edición, a la elección de los textos, al negocio de los libros y al encuentro con un público de lectores" ${ }^{29}$.

26 Figueroa Santacruz, «La Fotografía en Pasto», 145.

27 Beigel, «Las revistas culturales», 109.

28 También ofertaba para la venta en su almacén de fotografía: «Hortalizas cultivadas higiénicamente» y «las más bellas flores». Ilustración Nariñense, n 37 (1930): 1.

29 Roger Chartier, Cultura escrita, literatura e historia (México: Fondo de Cultura Económica, 2003), 59. 
Con los elementos que le aportaba el campo intelectual de la época y la práctica periodística, Delgado adelantó campañas por la consecución de un tratamiento más equitativo a la región sur de Colombia, informando exhaustivamente a los lectores sobre las posibilidades de progreso que traerían la vía férrea y las carreteras que se abrieran por entre los campos y las selvas de Nariño y Putumayo ${ }^{30}$. Sin embargo, es importante anotar con Beigel que "las trayectorias de los editorialistas muestran de manera privilegiada, como diría Lucien Goldman, que una obra es siempre un punto de encuentro tanto de la vida de un grupo como de la vida individual" ${ }^{31}$, y el trabajo de Delgado en la revista estuvo ligado al grupo de escritores regionales que alimentaron la publicación en forma frecuente.

\title{
Escritos y Escritores
}

Aunque con más de medio siglo de diferencia, la revista Ilustración Nariñense compartió con El Mosaico (Bogotá, 1858-1872) algunas características en el equipo de redacción. Loaiza, en su estudio sobre El Mosaico anotaba:

\begin{abstract}
El círculo de escritores bogotanos más cercano a la fundación de El Mosaico tenía ostensibles vínculos con las toldas conservadoras, católicas y filohispánicas; más aún, algunos de ellos no ocultaron ser una especie de representantes laicos del jesuitismo. Repartidores sistemáticos de lo que ellos estimaban decente y de buen gusto, tenían antecedentes de trasegados polígrafos: escritores de textos escolares, de cuadros de costumbres, de poesía didáctica y satírica, fundadores de periódicos y ocasionales redactores de leyes, constituciones o manuales de gramática. También habían frecuentado empleos del Estado y no ignoraban el recurso de las armas a la hora de las guerras civiles ${ }^{32}$.
\end{abstract}

30 Algunos artículos sobre el tema en la revista: «El Ferrocarril se acerca», n 15 (1926): 38; «Inauguración de los cinco primeros kilómetros del Ferrocarril de Nariño», n 17 (1926): 1; "Mensaje de Nariño a la primera autoridad de la Nación», n 90 (1945): 1; «El Cincuentenario de la Fundación del Departamento», n 116 (1954): 1-3; «En defensa de Tumaco - Levantar los rieles sería un error fundamental», n 116 (1954): 12-16.

31 Beigel, «Las revistas culturales», 111.

32 Gilberto Loaiza Cano, «La búsqueda de autonomía del campo literario. El Mosaico, Bogotá, 1858-1872», Boletín Cultural y bibliográfico 41, nº 67 (2004): 4-5. 
La historia, la literatura, el periodismo, la jurisprudencia o la educación fueron las temáticas a las que se adscribían los redactores de Ilustración, como oficio o como afición. La mayoría de ellos pertenecían a las filas conservadoras o al catolicismo conservador, entre quienes se encuentran los sacerdotes o religiosos que colaboraban con frecuencia, y algunos al partido liberal, en menor número. No hay menciones sobre un equipo de redacción permanente, pero sí se observa la participación frecuente de un grupo de intelectuales de diversos ámbitos. En algunos artículos, Delgado hace referencia a cronistas de la revista que realizaban entrevistas o labores de reportería ${ }^{33}$.

Entre los colaboradores más asiduos se encuentran los sacerdotes Aristides Gutiérrez (1862-1938), Samuel Delgado Ch. y Alejandro Ortiz López y los religiosos Hermanos Antonio de Padua y Anacleto ${ }^{34}$. Los tres primeros, muy cercanos a los aspectos literarios, participaron como jurados en los concursos convocados por la revista y escribieron acerca de jerarcas de la Iglesia católica o personas afines a ella. Abogados dedicados a la política como Federico Puertas, Manuel María Rodríguez (1868-1935), Ángel María Guerrero (¿-1934), José Elías del Hierro (1905-1991) y Olegario Medina tuvieron presencia frecuente con artículos acerca de la situación y el desarrollo de Nariño. Otros como Roberto Hinestrosa, escribieron sobre el Ferrocarril del Pacífico.

El historiador José Rafael Sañudo (1872-1943), contribuyó a menudo con ensayos acerca de la historia de la fundación de Pasto y la vida en la Colonia, las inequidades con que se había tratado al Departamento de Nariño y participó en polémicas resultantes de la publicación de su obra Estudios sobre la vida de Bolívar. La importancia de esta obra radicó "en haber puesto en tela de juicio la figura de Bolívar, en una época en que el culto a los mitos estaba muy bien cimentado

33 Un ejemplo «Doctor Ricardo Isaza Salom, quien fue entrevistado por uno de nuestros distinguidos cronistas, unos días antes de su viaje a Medellín, con motivo de tratar asuntos relacionados con la Compañía Tabacalera del Pacífico, de la cual es gerente en esta ciudad». Crayón, «Entrevista celebrada con el doctor Ricardo Isaza Salom», Ilustración Nariñense, ${ }^{\circ} 35$ (1929): 21.

34 J.V.R., «Ilustración Nariñense», Ilustración Nariñense, n 96 (1946): 8. 
y era considerado una necesidad para cohesionar el sentido centralista de nación" 35 .

La revista apoyó decididamente la obra de Sañudo y protestó porque no se pudiera hacer uso "de nuestros derechos de pensar y de escribir, de modo que con nuestras propias opiniones podamos ilustrar asuntos de carácter general y de valor histórico" ${ }^{36}$. Sin embargo, la publicación dio cabida a diferentes tendencias en el enfoque de los problemas históricos, como se puede apreciar al aceptar colaboraciones que apoyaban puntos de vista opuestos en la polémica en torno al Bolívar de Sañudo ${ }^{37}$. Un contradictor del escritor fue el historiador y humanista Sergio Elías Ortiz (1894-1978), quien refutó en varios artículos sus posiciones acerca de Bolívar, bajo el seudónimo de Un indio patriota, las cuales a su vez fueron respondidas por Sañudo con el seudónimo de Próspero Gallo $^{38}$.

Desde la orilla liberal, Plinio Enríquez (1878-1946) introdujo temas críticos acerca de la literatura y el arte en el terruño y en Latinoamérica y aportó una posición de vanguardia, tal como lo vivió en sus correrías por el Cono sur, donde tuvo contacto con escritores como Vicente Huidobro y Neruda.

Los poetas de la región tuvieron presencia frecuente, como es el caso de Luis Felipe de la Rosa (1878-1946) y

35 María Teresa Álvarez Hoyos, Élites intelectuales en el sur de Colombia. Pasto 1904-1930. Una generación decisiva. (Pasto: Editorial Universidad de Nariño, 2007), 335.

36 Eduardo Andrade, «Glosas sueltas. Un hijo indigno de Colombia», Ilustración Nariñense, $\mathrm{n}^{\circ} 12$ (1926): 14-15.

37 Jorge Martínez L., «Glosas al libro del Doctor Sañudo sobre Bolívar» (Tomado de Mundo al Día), Ilustración Nariñense, nº 11 (1926): 22-24; Eduardo Castillo, «El libro del Dr. Sañudo. Juzgado por un prestigioso intelectual» (Tomado de Doctrina Liberal), Ilustración Nariñense $\mathrm{n}^{\circ} 11$ (1926): 24; Fr. Heliodoro de Túquerres O.M.C., «Una rectificación y un reto al Dr. Sañudo», Ilustración Nariñense, n 29 (1928): 19.

38 Un indio patriota, «¿Historia?», Ilustración Nariñense, n 9 (1925): 3-4; Un indio patriota, «¿Historia? VI», Ilustración Nariñense, $\mathrm{n}^{\circ} 10$ (1925): 20-22; Próspero Gallo, "Los refutadores del señor José Rafael Sañudo», Ilustración Nariñense, n 10 (1925): $22-24$. 
Cecilia Guerrero Orbegozo (1913-1951). Las biografías de personajes destacados del departamento estuvieron a cargo de Temístocles Pérez Delgado (1894-?) y Teófilo Albán Ramos (¿-1944). Estos artículos han permitido tener un conocimiento más preciso de las élites intelectuales de la época, que de otra forma hubiera desaparecido con sus contemporáneos.

Los humanistas e historiadores de reconocimiento nacional e internacional Leopoldo López Álvarez (1891-1940), José Rafael Sañudo (1872-1943), Sergio Elías Ortiz (18941978) e Ignacio Rodríguez Guerrero (1911-1983) contribuyeron con artículos de historia regional, literatura o análisis sobre problemas sociales. Jorge Buendía (1895-1991), educador formado en Chile, aportó artículos sobre la educación y las instituciones educativas de la ciudad; Guillermo Edmundo Chaves (1903-1984), autor de la novela Chambú y José Rafael Zarama (1870-1940), historiador, escribieron también en la revista.

Como colaboradores ocasionales encontramos a Agustín Nieto Caballero (1889-1975) educador, escritor y diplomático y a su hermano Luis Eduardo Nieto Caballero (1888-1957) diplomático, periodista y político liberal, Alberto Quijano Guerrero (1919-1995) humanista y escritor nariñense, Francisco Albán, Alfonso Alexander (1907-1985) polémico escritor liberal, Eduardo Andrade, Alberto Montezuma Hurtado (1906-1986) escritor, historiador y político liberal, Eliseo Gómez Jurado (1864-1951) político conservador, Benjamín Guerrero (1862-1940) militar en la guerra de los Mil Días y escritor conservador.

\section{Temáticas}

La revista, presentada en forma de magazine, se editaba mensualmente ${ }^{39}$ en un formato de $23 \times 32 \mathrm{~cm}$., en cuadernillos de 34 páginas, y contenía artículos comúnmente tratados por los diarios pero expuestos en forma más extensa. Comprendía

$\overline{39}$ No siempre fue posible editarla mensualmente, especialmente en los años cuarenta y cincuenta. 
diferentes secciones: comentarios y voces de aliento a la publicación, editoriales escritos por el director o alguien de su equipo, generalmente dedicados a temas de actualidad como las candidaturas a la presidencia, la construcción del ferrocarril o el desarrollo del Departamento de Nariño, temas de historia, página pedagógica, el estado de la educación regional, la literatura en Nariño y crónicas acerca de personajes de la política, el arte y la literatura ${ }^{40}$. Se encuentran artículos sobre la guerra europea, enfermedades como la tuberculosis y su afectación a determinadas poblaciones, análisis sobre los volcanes de Nariño y exposición de las visitas a ciudades del Departamento o del país.

La relación periodismo y política, que en nuestro país ha sido constante desde el siglo XIX, también se aprecia a lo largo de la existencia de la longeva revista. Ilustración, a pesar de sus manifestaciones de no incursionar en banderismos políticos, divulgó el discurso conservador, tanto a través de artículos que reflejaban la lealtad partidista como a través de escritos que cuestionaban las medidas adoptadas por los gobiernos liberales, como la reforma constitucional. Para Darío Acevedo, en el período comprendido entre los años 30 y 50 existió una estrecha relación entre periodismo, política y poder, dado que "el periodismo ha sido uno de los vehículos esenciales del proceso de afirmación de las lealtades e identidades partidistas" ${ }^{41}$.

40 Con frecuencia se publicaron artículos referidos al estado de la literatura en Nariño, con la mención de escritores, poetas y poetisas de la región, como los siguientes: M.A. Domínguez Muñoz, «El valor del conocimiento y la Feria del Libro. La contribución de los nuestros en la cultura pública. La Feria Magnífica institución», Ilustración Nariñense, $\mathrm{n}^{\circ} 98$ (1946-1947): 4-5; Rafael Delgado, "La cultura de un pueblo», Ilustración Nariñense, $\mathrm{n}^{\circ} 101$ (1949): 20-23; en este artículo hace un recuento de los instrumentos de divulgación cultural como las bibliotecas y librerías y entrevista al propietario de una librería sobre libros, lectores y sistemas de venta.

41 Darío Acevedo, «Prensa y confrontación política en Colombia 1930-1950», en Medios y nación. Historia de los medios de comunicación en Colombia. VII Cátedra Anual de Historia Ernesto Restrepo Tirado. (Bogotá: Ministerio de Cultura, Aguilar, 2003), 285. 


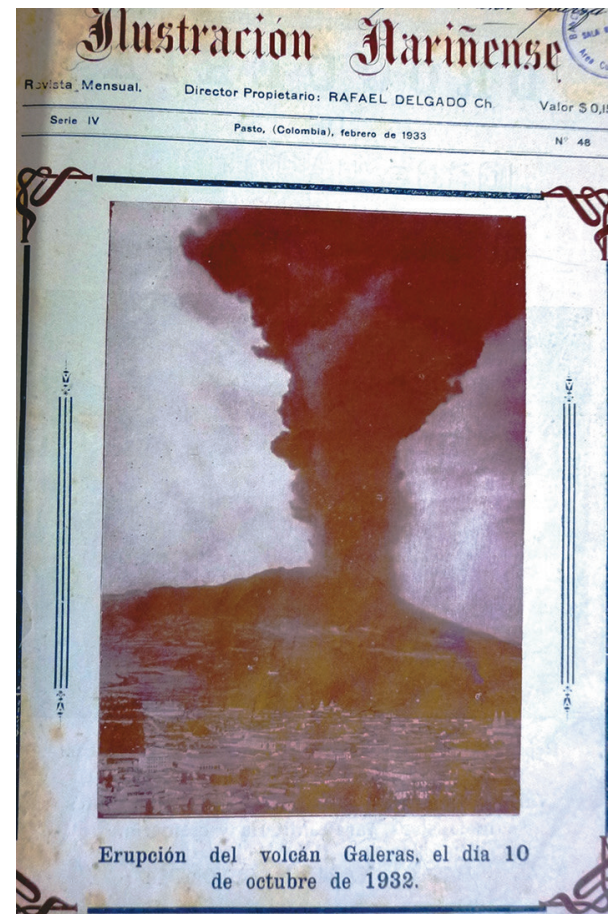

Imagen 4. Erupción del volcán Galeras, el día 10 de octubre de 1932. Fuente: Portada Ilustración Nariñense, $\mathrm{n}^{\circ} 48$ febrero de 1933.

En 1929, el respaldo fue para el general Alfredo Vásquez Cobo, quien competía por el voto conservador con el maestro Guillermo Valencia y había ofrecido apoyar la línea férrea Popayán - Pasto ${ }^{42}$. En 1946, la revista destacaba elogiosamente el perfil del candidato Mariano Ospina Pérez, e invitaba a votar no solo por el programa que proponía "sino porque tiene el propósito irrevocable de construirnos los ferrocarriles que necesitamos para el desarrollo efectivo del progreso departamental"43. A Darío Echandía, candidato liberal en visita previa a las elecciones de 1946, lo llamaba "el candidato del continuismo" 44 .

42 «Concentración. Vásquez Cobo y Valencia», Ilustración Nariñense, nº 35 (1929):1-2.

43 Rafael Delgado, «Dr. Mariano Ospina Pérez, candidato de la Unión Nacional a la Presidencia. Lo que significa para Nariño el triunfo de su nombre en las elecciones del 5 de mayo», Ilustración Nariñense, nº 95 (1946): 2.

44 Rafael Delgado, «Las visitas a Nariño de los candidatos a la primera magistratura de la República y la construcción del ferrocarril de Popayán a la frontera con el 
En 1950, con la elección de Laureano Gómez como presidente de la República para el período 1950-1954, se expresaba así: "Hombre de la más recia contextura moral, excelsa figura de las letras castellanas, invicto caudillo y famosísimo orador, lleva más de 20 años de lucha incesante en los estadios del diarismo nacional, como paladín augusto de la 'Causa de la Libertad dentro del Orden' "45.

A las congregaciones religiosas y sacerdotes - bodas de oro, conmemoraciones y defunciones - se les daba lugar destacado, al igual que a vías de comunicación y transporte. Las Notas Sociales no faltaban y la mención a los Concursos literarios o deportivos que promovía la Revista incluía los conceptos elaborados por los jurados.

Para conmemorar el centenario de la muerte del Libertador, la dirección de Educación Pública dedicó la semana comprendida entre el 14 y el 21 de diciembre de 1930 y dispuso que

[...] la luctuosa efemérides se celebrará en forma digna y solemne en todos los ámbitos de la tierra nariñense, consagrando la atención de sus habitantes a evocar la gloriosa memoria del Padre de la Patria durante una semana, en cuyo tiempo deberían verificarse actos alusivos al magno centenario, a fin de testificar el profundo respeto y gratitud reverente que los nariñenses guardan para el Libertador Simón Bolívar ${ }^{46}$.

La información correspondiente a dicha celebración se publicó en un número extraordinario encargado para el efecto por la dirección de Educación. Con el mismo objeto y también con un número de la revista dedicado a los actos conmemorativos, la Sociedad "Unión Popular Católica" de Pasto llevó a cabo el 17 de diciembre de 1930 una exposición

Ecuador», Ilustración Nariñense, $\mathrm{n}^{\circ} 91$ (1945): 1.

45 «Excmo. Sr. Dr. Laureano Gómez, Presidente Constitucional de la República de 1950 a 1954», Ilustración Nariñense, $\mathrm{n}^{\circ} 102$ (1950): 1.

46 Jorge Buendía, «Centenario de la muerte del Libertador y su conmemoración en el Departamento de Nariño», Ilustración Nariñense, $\mathrm{n}^{\circ}$ extraordinario publicado por la Dirección de Educación Pública (1930): 1. 
artística, agrícola e industrial en homenaje "de veneración y de reconocimiento a las excelsas virtudes sociales del Padre de la Patria" ${ }^{47}$. Cabe anotar que las exposiciones agrícolas e industriales desde fines del siglo XIX se llevaban a cabo en fechas que tenían que ver con mitos fundacionales como el 20 de julio o el 7 de agosto, con el fin de que el discurso de la nación penetrara en la conciencia del pueblo.

En el mismo número ${ }^{48}$, Rafael Eraso Navarrete, líder cívico de la región, presentó informe sobre el resultado obtenido por el Departamento de Nariño en la Exposición Iberoamericana de Sevilla, clausurada en junio de 1930. En dicha exposición, en la Sección de Periodismo, obtuvo primer premio y medalla de oro el Boletín del Centro de Historia de Pasto y segundo premio y medalla de oro Ilustración Nariñense, como revista ilustrada. En la Sección de Fotografía, Cinematografía y aplicaciones, el señor Rafael Delgado obtuvo "mención honorífica" 49 .

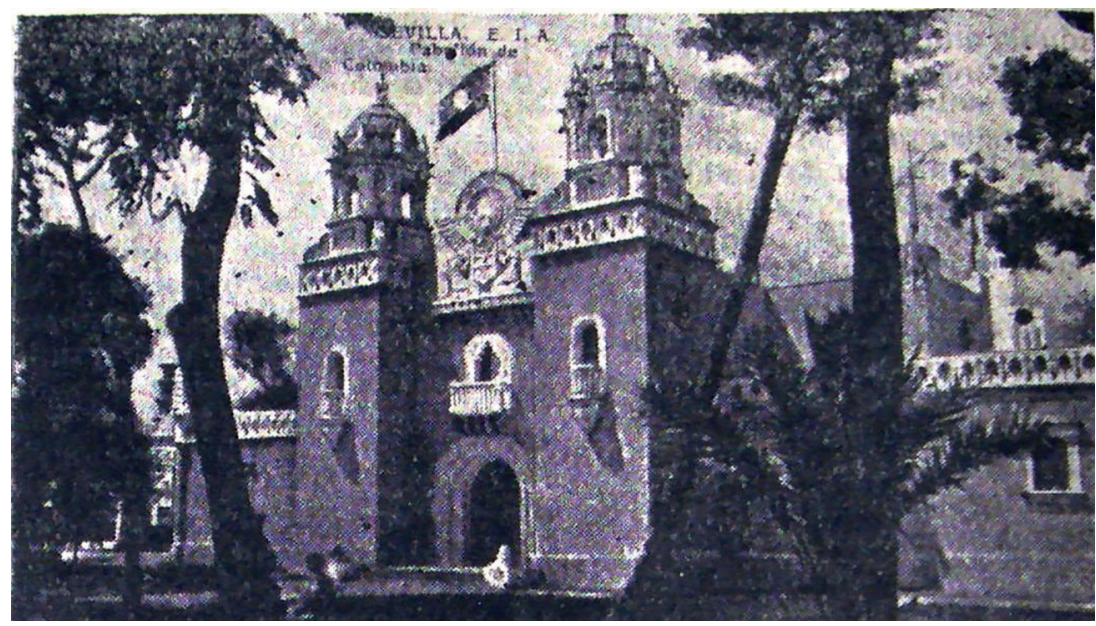

Imagen 5. Pabellón de Colombia en la Exposición Iberoamericana de Sevilla Fuente: Ilustración Nariñense n $^{\circ} 43$ julio de 1931.

47 Luis F. Fajardo, «El Centenario del Libertador y la Sociedad "Unión Popular Católica" de Pasto», Ilustración Nariñense, nº 43 (1931): 1.

$48 \mathrm{n}^{\circ} 43$ de julio de 1931.

49 Rafael Eraso, «Informe del doctor Rafael Eraso Navarrete, delegado por Nariño, sobre el resultado obtenido por el Departamento en la Exposición Iberoamericana de Sevilla», Ilustración Nariñense, n 43 (1931). 
La revista mantuvo constantes los tipos de temáticas a tratar, conservando siempre la presencia de un equipo de escritores locales, que redactaban los artículos de fondo. El director usualmente tocaba los temas polémicos, como la posición del gobierno frente a la construcción del Ferrocarril del Pacífico, la carretera a Popayán o la posición de la Revista frente a la reforma de la constitución en la etapa de López Pumarejo. No se tiene noticias si la revista dio lugar a alguna tertulia o equipo permanente, pero sí se observa que los colaboradores se repiten en sucesivos números.

En su estructura, se puede decir que "guarda resabios de la tendencia 'enciclopédica' presente a veces en las revistas modernistas y que se mantiene en las publicaciones culturales de las décadas siguientes" ${ }^{50}$, con la presencia de artículos sobre literatura, economía, pedagogía, secciones informativas, de correspondencia, notas y documentos y reseñas de revistas y libros ${ }^{51}$.

La duración de la publicación a lo largo de 30 años permitió seguir la trayectoria de empeños como la instalación del ferrocarril, del cual se puede decir que la revista publicó todo el proceso, desde el júbilo inicial por la aprobación en el Congreso hasta el desengaño de ver levantados los rieles de la línea férrea.

50 Flora Ovares, «Crónicas de lo efímero: un siglo de revistas culturales y literarias costarricenses", Revista Iberoamericana LXX, n 208 y 209 (2004): 1007. El comentario se refiere a la Revista Repertorio Americano, dirigida por Joaquín García Monge, desde 1919 hasta 1959.

51 En el n 59 de 1936 hay una reseña de la Revista América Española, «una revista científico-literaria que sale cada mes en Cartagena 'La Heroica', y que dirige con acierto el eminente publicista doctor Gabriel Porras Troconis». El editor invita a suscribirse a esta publicación como también a «la Revista Colombiana que se edita en Bogotá para que gocen con la lectura de producciones verdaderamente útiles». En el mismo sitio, reseña el nuevo libro de Sergio Elías Ortiz, Las Comunidades indígenas de Jamondino y Males: «Es un estudio bastante curioso del tipo indígena que todavía se ha conservado en Nariño, de sus costumbres, cualidades y defectos. En su libro aboga el autor por el mejoramiento de los que fueron poseedores de parte de las selvas americanas antes de la Conquista». Rafael Delgado, Ilustración Nariñense, $\mathrm{n}^{\circ} 59$ (1936): 27. 


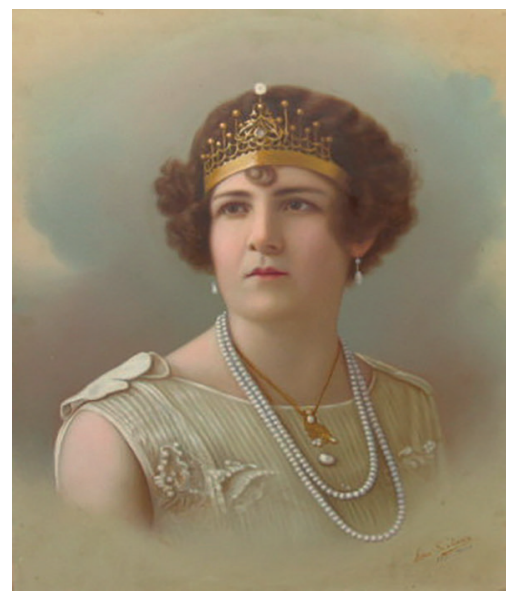

Imagen 6. Romelia Martínez, Reina de los Estudiantes 1926.

Fuente: Casa Museo Maestro Alfonso Zambrano, Pasto.

Foto: Adriana Zúñiga Álvarez.

Las menciones a las mujeres se centran en las formas aceptables de un yo femenino público, presente hasta las primeras décadas del siglo XX, en que se despliega el "convencionalismo efusivo" de las poetisas ${ }^{52}$, con cabida frecuente a poemas de mujeres y referencias a las que han logrado publicaciones en periódicos y revistas de la ciudad. Por lo general, el interés se centra en la poesía o alguna otra manifestación del arte, como la música ${ }^{53}$. Por otro lado, encontramos crónicas "galantes" sobre la elección de las reinas locales - "su majestad Romelia I", reina de los estudiantes o "su majestad Clemencia I de Ipiales, Reina del Arte y de la Melodía y Señora del Trabajo" ${ }^{44}$ - en las que destacan el papel de la mujer como ornato de la sociedad con profusión de fotos y discursos de proclamación.

52 Silvia Molloy, en su ensayo «Dos proyectos de vida: Norah Lange y Victoria Ocampo» (Filología XX, n 2), citada por Beatriz Sarlo, Una modernidad periférica: Buenos Aires 1920 y 1930. (Buenos Aires: Ediciones Nueva Visión, 1988), 70.

53 «Una embajada artística», Ilustración Nariñense, $\mathrm{n}^{\circ} 56$ (1934). El artículo transcribe el discurso dedicado a la poetisa Laura Victoria, en el recital realizado en el Teatro Imperial y a la participación de la joven Maruja Hinestrosa en la ofrenda musical.

54 «Su Majestad Clemencia I de Ipiales», Ilustración Nariñense, nº 12 (1926): 17. 


\section{Ilustración Nariñense y la creación de región}

La actividad periodística y ensayística de iniciativas como la de Ilustración Nariñense intentó quebrar el aislamiento intelectual de la comarca y propiciar la discusión y difusión de los intereses y problemas regionales. Yazmín López, al referirse al Perú de comienzos del siglo XX, plantea que este tipo de incursiones periodísticas inauguraron nuevos espacios de disputa cultural e ideológica, permitiendo el ascenso de "una multiplicidad de nuevos sujetos productores dentro del ámbito de la cultura letrada" pero sobre todo, patrocinando "una explosión de narrativas sobre la nación" 55.

Ilustración contribuyó a la formación de un imaginario colectivo sobre el progreso de la región que pasaba por lograr una comunicación expedita con el mar, con la capital del país, con el Ecuador y con el Putumayo; situación que posibilitaría sacar las riquezas que, según decían, estaban desperdiciadas por no tener vías ágiles de comunicación.

La fe en el progreso sedujo a la clase política - entusiasmo también compartido por el pueblo raso - quienes cifraron sus expectativas en el ferrocarril como instrumento de progreso por excelencia, ya que garantizaba la movilidad de personas y productos. Un pasaje de Gastineau, citado por Benjamín, retrata el tono del discurso frente a la máquina en la segunda mitad del siglo XIX:

¡Salud a vosotras, bellas razas del porvenir nacidas gracias al ferrocarril!" "¡Al vagón! ¡al vagón! el toque de silbato ha sonado agudo bajo las bóvedas sonoras de la estación." "Antes de la creación de los ferrocarriles, la naturaleza no palpitaba aun; era una Bella durmiente del bosque (...); los cielos mismos parecían inmutables. El ferrocarril lo ha

55 Yazmín López Lenci, «La creación de la nación peruana en las revistas culturales del Cusco (1910-1930)», Revista Iberoamericana LXX, nº 208 y 209 (2004): 697-720. La Sierra y Revista Universitaria, fueron iniciativas cusqueñas con el fin de producir un discurso regional. La Sierra pretendió la cohesión intelectual de la generación emergente cusqueña, acudiendo al prestigio del pasado y la Revista Universitaria se propuso «abordar científicamente la realidad de la región del Cusco bajo diferentes disciplinas aunque concentró sus esfuerzos en redimensionar los estudios históricos». López Lenci, «La creación de la nación», 697-698. 
animado todo (...) El cielo se ha convertido en un infinito activo, la naturaleza en una belleza en acción ${ }^{56}$.

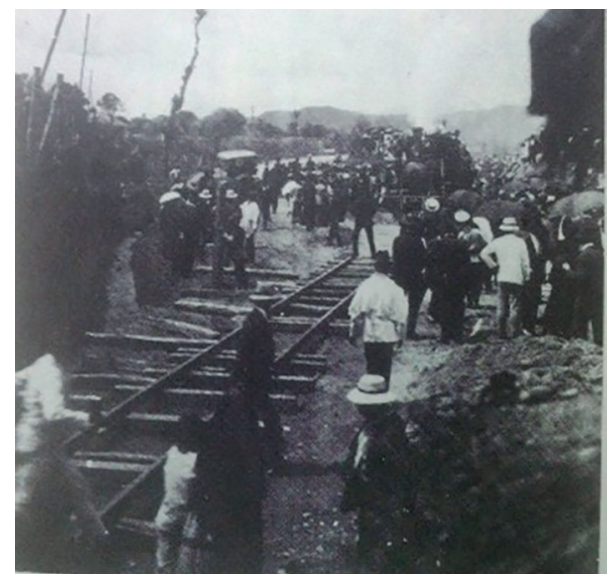

Imagen 7. Construcción de línea férrea.

Fuente: Pasto a través de la fotografía. Banco de la República 1989.

La ley 62 de 1923 tuvo su concreción en el inicio de la obra del ferrocarril de Tumaco a Pasto, gracias al superávit fiscal de que gozó el país en el gobierno de Pedro Nel Ospina (19221926), con el pago de 25 millones de dólares que hicieron los Estados Unidos a Colombia como indemnización por el robo de Panamá; de estos, el 65\% se destinaron a la construcción de ferrocarriles y vías de comunicación ${ }^{57}$.

Se dio autorización para elevar a dos mil el número de trabajadores; se pidieron al exterior rieles para 30 kilómetros y algunos elementos de material rodante. La explanación avanza de Aguaclara al Diviso. Esa vía férrea dará la señal de triunfo y marcará el Departamento de Nariño con sello definitivo llevándole abundancia y renovación con el soplo oceánico, que es el aliento vital del mundo ${ }^{58}$.

56 Benjamín Gastineau, La vida en ferrocarril, París, 1861, citado en Walter Benjamín, Libro de los Pasajes, ed. Rolf Tiedemann (Madrid: Ediciones Akal, 2005), 602-603.

57 Santiago Castro-Gómez, Tejidos Oníricos. Movilidad, capitalismo y biopolítica en Bogotá (1910-1930) (Bogotá: Editorial Pontificia Universidad Javeriana, 2009), 71.

58 Teófilo Albán Ramos, «El Departamento de Nariño», Ilustración Nariñense, n 12 (1926): 4 . 
La colocación del primer riel del ferrocarril dio lugar a celebraciones y festejos; en el editorial del 31 de julio de 1926 se anotaba que este acontecimiento:

\begin{abstract}
Ha tenido en todo el Departamento repercusión y alcances incalculables en todo orden de ideas y de aspiraciones. La moral colectiva se ha levantado considerablemente; y todos los nobles estímulos de la dignidad y del esfuerzo se suscitan por los ámbitos de Nariño, prometiendo la cosecha ubérrima del porvenir, digna de la vid latina, cuya sangre y cuya alma informa a nuestra raza ${ }^{59}$.
\end{abstract}

Para la celebración, el gobernador accedió a la petición de festejar "tan extraordinario acontecimiento con corridas públicas de toros" ${ }^{60}$. El programa se extendió entre los días 3 y 6 de julio, en los que hubo Misa solemne y Te Deum, desfile cívico, retreta de gala, partido de fútbol, concurso de tiro y ejercicios gimnásticos, conferencia sobre medios de locomoción y transportes, cine público y corridas de toros, presididas por "su majestad Romelia I"61.

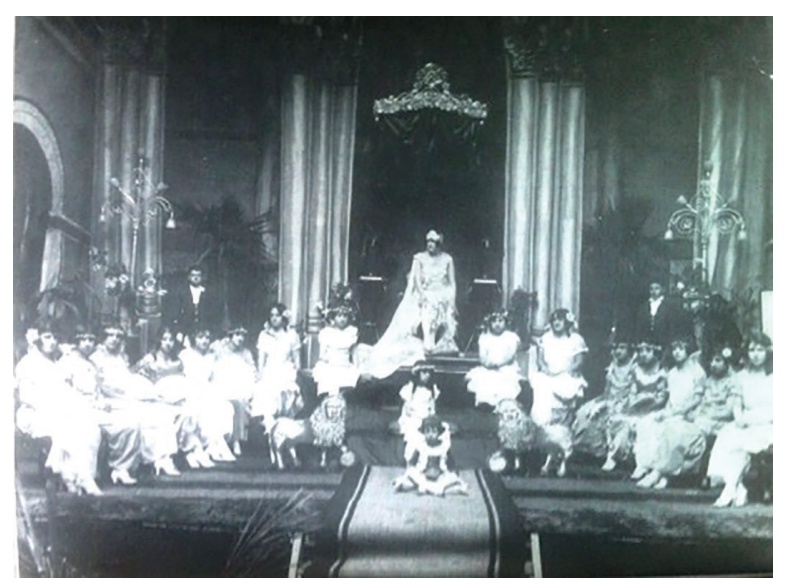

Imagen 8. Coronación de la Reina de los Estudiantes, Romelia I. Fuente: Ilustración Nariñense No. 11 Febrero 1926.

59 «Ferroviar es mejorarse y tener más altas miras», Ilustración Nariñense, $\mathrm{n}^{\circ} 13$ (1926): 3.

60 «Vivan los toros! ¡Viva el Ferrocarril de Nariño! ¡Viva el entusiasmo!», Ilustración Nariñense, $\mathrm{n}^{\circ} 13$ (1926): 7.

61 «Programa de festejos para celebrar la colocación de los primeros rieles del Ferrocarril de Nariño», Ilustración Nariñense. n 13 (1926): 7. 
Todo lo que representara la movilidad, el impulso a las vías de comunicación, lo que significara romper el aislamiento que las condiciones geográficas habían impuesto, se difundía y amplificaba a través de la revista. En el No. 40 de 1931, en la sección Noticias Importantes se informaba que "en Nariño se ha comenzado con formidable empuje la carretera del Norte; trabajan en ella 1500 fornidos obreros ayudados de magnífica maquinaria" 62 .

Acercar a las personas y a sus productos, rompiendo el aislamiento al que parecía condenarlas la naturaleza, es entonces la función económica y moral de las vías de comunicación. Las redes de transporte - y en particular las redes ferroviarias - crearán una "naturaleza segunda" que corregirá los defectos de la naturaleza primera, origen del aislamiento económico y la inmoralidad que se observa en el país. Se trata, pues, de combatir las abruptas condiciones topográficas del país y vencerlas mediante la creación de una infraestructura técnica ${ }^{63}$.

Adentrarse en la creación de tal infraestructura exigía desarrollos en el campo de la ingeniería que fueran a la par con una economía regional boyante y productiva; sin embargo, estos dos factores van a incidir irremediablemente sobre el futuro del ferrocarril en Nariño, cuando la realidad de las condiciones de producción precapitalista de la región, evidencie las dificultades para rentabilizar un empeño de tal magnitud. La capacitación técnica la había impulsado la élite dirigente de Nariño en la primera década del siglo XX, con la Facultad de Matemáticas e Ingeniería dirigida por Fortunato Pereira Gamba, empeño que se vio truncado por la caída del general Rafael Reyes y del gobernador Bucheli en 1909. Posteriormente, la facultad fue reabierta en la década del veinte con esporádicos cierres y problemas para la consecución de profesores y de alumnos. A pesar de ello, a comienzos de los años treinta había logrado formar unos pocos ingenieros y agrimensores que se ocuparon de las labores de ingeniería.

62 "Noticias importantes. Adelantos de las carreteras colombianas en este año», Ilustración Nariñense, $\mathrm{n}^{\circ} 35$ (1935): 20.

63 Castro-Gómez, Tejidos oníricos, 67-68. 
En 1930, los rieles del ferrocarril habían unido el tramo El Diviso - Agua Clara (a $17 \mathrm{~km}$. de Tumaco) y se esperaba que esta vía rápida hacia el Pacífico activara el desarrollo de la región, al tiempo que se aprovecharía la apertura del Canal de Panamá para intensificar el movimiento comercial en el puerto de Tumaco. La prensa local invitaba a los nariñenses a sostener un flujo de mercancías que permitiera costear los gastos que demandaba el ferrocarril; sin embargo, al poco tiempo se evidenciaron las dificultades por la falta de mercancía suficiente y "por los varios y costosos trasbordos de la carga que circula entre Pasto y Tumaco o viceversa y que recarga de una manera exorbitante el precio de los artículos" ${ }^{3}$.

Por otra parte, desde 1928 el gobierno colombiano dejó de recibir recursos de crédito externo, lo cual unido a la baja de los precios del café y las circunstancias del desplome de la bolsa de Nueva York en 1929, condujeron a paralizar la financiación de las obras de infraestructura en el país ${ }^{65}$. No obstante, los nariñenses persistieron en su empeño por continuar la vía férrea entre Popayán y Tumaco. En 1938, Ilustración destacaba la gestión del nuevo gobernador Alberto Montezuma Hurtado "pues no se escapa a su visión inteligente, de que solo obtendremos progreso efectivo, cuando Nariño se halle unido al corazón de la patria mediante las paralelas de hierro (...) Desde el punto de vista del honor nacional, facilita la movilización de tropas para la defensa"66.

En 1945, los representantes por Nariño al Congreso lograron la aprobación de la ley No. 26 que dispuso la construcción del ferrocarril troncal de occidente, desde Cartagena hasta Tumaco, pero "en 1948 la misión ferroviaria americana y posteriormente la misión Currie, aconsejaron al gobierno suspender esas obras, levantar los rieles de algunas

64 Alonso Restrepo, Apuntes, notas y algunos comentarios del Médico de la Comisión de Cultura Aldeana que visitó el Departamento de Nariño (Medellín: Imprenta Oficial, 1935), 86.

65 Rosa Isabel Zarama, «Historia del Ferrocarril de Nariño», Tendencias 17, n 1 (2016): 97.

66 Rafael Delgado, «El doctor Alberto Montezuma y el Ferrocarril de Popayán a la frontera ecuatoriana», Ilustración Nariñense (1938): 1. 
secciones como Nariño y construir el ferrocarril del río Magdalena"67.

Cuando el levantamiento de los rieles era una realidad, Rafael Delgado escribió:

Arrancar los rieles del Ferrocarril sería arrancar el alma del pueblo de Nariño y el mayor ultraje que se nos puede inferir. Seríamos capaces de marchar compactos a pedir al Excmo. señor presidente no solo la conservación de los rieles de nuestra ferrovía sino también que se continúe urgentemente su construcción hasta Pasto ${ }^{68}$.

\section{Tanto Ilustración Nariñense como Letras - otra revista} cultural editada en Pasto en los años cuarenta -

llevaron a sus páginas la discusión que se daba en el centro del país acerca de reemplazar el tren por una carretera (...) Entre los nariñenses hubo un gran desasosiego al conocer que la vía terrestre se estaba construyendo sobre el terraplén ferroviario ${ }^{69}$.

\section{¿Quiénes eran los lectores?}

La zona de difusión de la revista es una forma de constatar el impacto de la publicación. "Es evidente que la primera zona de difusión es la de la ciudad en que se edita la revista, pero cuando hay canjes, distribución internacional, o corresponsalías, la revista expande su zona y llega a lugares lejanos y tal vez insospechados"70. Respecto a la acogida que Ilustración tenía entre el público, Delgado expresaba:

Eso de que nuestra modesta Revista sea solicitada de distintos lugares del país, de que sea leída con interés por el letrado y por el de mediana cultura, por el eclesiástico y por el hombre de negocios, por la grave matrona y por la joven

67 CERO (Carlos Teófilo Rosero), «El Levantamiento de los Rieles del Ferrocarril de Nariño», Ilustración Nariñense, $\mathrm{n}^{\circ} 112$ (1953): 5.

68 Rafael Delgado, «La levantada de los rieles del Ferrocarril de Nariño», Ilustración Nariñense, $\mathrm{n}^{\circ} 120$ (1955): 1-2.

69 Zarama, «Historia del Ferrocarril», 99.

70 Pita González y Grillo, «Una propuesta de análisis». 
de quince abriles; sin que le tengan recelo tirios y troyanos, eso solo, decimos, nos colma de satisfacción y es la voz más elocuente de nuestra sinceridad para con la sociedad a la que tenemos la honra de pertenecer ${ }^{71}$.

En los correos publicados como "Voces de aliento", felicitan al director por "las páginas sustanciosas y los fotograbados tan nítidos [los que] dicen muy alto de la cultura y progreso de nuestro departamento" 72 . En diferentes números se reportan comentarios enviados desde Samaniego, Buga, Cartago, Tumaco, Popayán, Bogotá, Cali, Ibagué ${ }^{73}$. En otras ediciones menciona las expresiones de felicitación hechas por periódicos de ciudades como Cali, Relator y Diario del Pacífico ${ }^{74}$, Medellín, El obrero católico y La Defensa, Calarcá, Revista Luz de Calarcá ${ }^{75}$ y Panamá, Motivos Colombianos ${ }^{76}$.

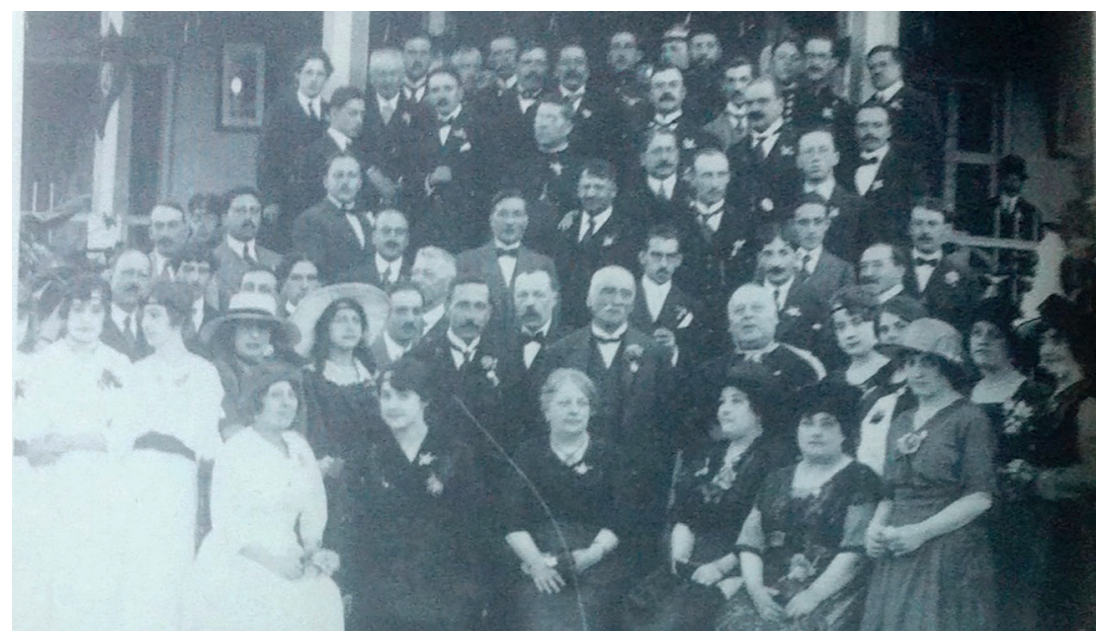

Imagen 9. "El señor Marco Fidel Suarez en la Quinta del señor Julián Bucheli, rodeado de distinguidos miembros de nuestra Sociedad"

Fuente: Ilustración Nariñense, n 5 Marzo 1925.

71 Rafael Delgado, «El Número 12 de nuestra Revista», Ilustración Nariñense, $\mathrm{n}^{\circ} 12$ (1926): 1.

72 «Voces de aliento», Ilustración Nariñense, n 12 (1926): 35.

73 «Voces de aliento de distintos lugares», Ilustración Nariñense, nº 60 (1936): 3-4.

74 «Relator, Diario del Pacífico y Adelante estimulan nuestra labor», Ilustración Nariñense, $\mathrm{n}^{\circ} 60$ (1936): 1-2.

75 Gonzalo Uribe Mejía, «Ilustración Nariñense», Ilustración Nariñense, $\mathrm{n}^{\circ} 35$ (1929): 16-17.

76 «Nuestra Revista en Panamá», Ilustración Nariñense, n 17 (1926): 18. 
El Comercio de Quito comentaba:

En vista de algunos números de Ilustración Nariñense, podemos asegurar que es un apreciable exponente que honra a Pasto. Salvando el marcado misticismo propio del medio ambiente retraído en que Ilustración Nariñense se edita, contiene sabrosos artículos y amenas secciones (...) Nos sorprende el adelanto del periodismo en estos días y el impulso que van tomando las artes gráficas ${ }^{77}$.

Las "Notas Sociales" se publicaron en casi todas las ediciones y en ellas se reportan viajeros, festividades, matrimonios, condolencias, nombramientos, huéspedes ilustres, anuncios sobre "últimas publicaciones recibidas" o eventos de reciente ocurrencia como el incendio de Barbacoas en 1933.

Otra forma de vinculación con los lectores la propició la revista a través de los concursos literarios y deportivos:

En los tiempos modernos el periódico ya dejó de ser solo noticioso o comercial para convertirse en el portaestandarte de la verdadera civilización. Ilustración Nariñense consciente de este deber de la hora presente - ha promovido y llevado a término cinco concursos, dos deportivos y tres literarios ${ }^{78}$.

El primer concurso literario se llevó a cabo en 1924, con dos secciones de prosa y verso; en la sección de prosa fueron ganadores Luis Samuel Fajardo, Sergio Elías Ortiz y Temístocles Pérez Delgado. El segundo concurso literario tuvo lugar en la navidad de 1925 con el tema Un cuento de Navidad, al que solo se presentaron cinco trabajos. El tercer concurso literario lo promovió la revista en mayo de 1933, con motivo de llegar al No. 50, "para premiar el mejor cuento, la

77 «Ilustración Nariñense», Ilustración Nariñense, n 15 (1926): 44.

78 Alejandro Ortiz López, «Diez años de labor de la Revista Ilustración Nariñense. Discurso de Introducción del R.P. Alejandro Ortiz López S.O. en la velada líricoliteraria con ocasión de la distribución de premios», Ilustración Nariñense, $\mathrm{n}^{\circ} 55$ (1934): 2. 
mejor poesía y la mejor pieza de música"79. Luis Eduardo Nieto Caballero fue jurado nacional de la sección de prosa y Luis María Mora de la sección de verso; los trabajos de música los juzgaron Emilio Murillo y algunos músicos del Conservatorio nacional ${ }^{80}$.

En cuanto a los concursos deportivos, el primero se realizó en 1924 y el segundo se abrió en junio de 1929, “con el fin de preparar las fuerzas deportivas del departamento a las olimpiadas nacionales que se llevarían a efecto en Cali" ${ }^{1}$.

En 1946, la revista convocó un concurso literario con motivo del triunfo de la campaña periodística en pro de la construcción del ferrocarril Popayán-Pasto-Ipiales y terminación del de Tumaco a Pasto, campaña que culminó con la expedición de la ley 26 de 1945, y por aproximarse la revista a su centésima edición ${ }^{82}$. Se abrieron tres concursos: el primero entre historiadores, con el tema "El crimen de Berruecos", "tratando de poner en claro con documentos auténticos, quien fue el autor intelectual del asesinato del Gran Mariscal de Ayacucho". El segundo entre prosistas, "les proponemos un ensayo de novela corta" y el tercer concurso, exclusivamente para poetisas, una composición en verso ${ }^{83}$ :

Con estos certámenes, que indudablemente serán bien recibidos por los amantes de la Historia del país y de las bellas letras, nos proponemos dar la mano a literatos que permanecen acaso en la oscuridad, por falta de estímulo adecuado, teniendo de presente que a base de nuestros torneos literarios, celebrados con notable éxito en diversas ocasiones, durante la vida de esta revista, acrecentaron su prestigio ante la sociedad consciente, como inspirados poetas y prosistas de nota y se colocaron en el puesto de honor que les corresponde los siguientes escritores:

79 «Concurso Literario-Musical de Ilustración Nariñense», Ilustración Nariñense, n 49 (1933): 11.

80 Ortiz López, «Diez años de labor», 2-5.

81 Ortiz López, «Diez años de labor», 2.

82 Rafael Delgado, «Concurso literario. La llegada de 'Ilustración Nariñense' al número 100», Ilustración Nariñense, n 97 (1946): 1.

83 Delgado, «Concurso literario», 1. 
Alberto Montezuma Hurtado, Sergio Elías Ortiz, Temístocles Pérez Delgado, Luis Felipe de la Rosa, Guillermo Edmundo Chaves, Manuel Quiñones, Luis Perdomo Torres, Leopoldo López Álvarez, Carlos Cesar Puyana, Francisco Albán, Pedro María Dávalos, Manuel Delgado y la Sra. Zoila Rendón de Mosquera ${ }^{84}$.

En 1933, Ilustración fue invitada a entrar en canje con la revista Ibero-Amerikanisches Archiv, del Ibero Amerikanisches Institut, como muestra del reconocimiento que había adquirido y de las posibilidades de que la región fuera conocida por los lectores de los fondos del Instituto.

En el deseo de poner a la disposición de nuestros lectores una documentación la más completa de las publicaciones colombianas de importancia, me dirijo a Ud. para proponerle entrar en canje entre nuestra revista trimestral "IberoAmerikanisches Archiv» y el órgano de su digna dirección, de tal manera que Ud. se serviría favorecernos regularmente con los números de la revista "Ilustración Nariñense». En el caso de aceptación inscribiríamos la revista "Ilustración Nariñense» en nuestra lista de canjes. Si fuera posible agradeceríamos mucho la extensión del canje a todos los números ya publicados de nuestra revista (...) En espera de su grata contestación, le saluda atentamente,

Berlín, Ibero Amerikanisches Institut. Edith Faupel ${ }^{85}$.

En marzo de 1945, J.M. Sheppard, Director de South American Digest, desde Quito se dirige al director Delgado:

La revista que usted dirige ha llamado nuestra atención por sus artículos relacionados con Sud América. Desde enero del presente año hemos iniciado la publicación mensual de SOUTH AMERICAN DIGEST, en inglés, con el objeto de llevar al pueblo de los Estados Unidos una expresión genuina de la literatura de Sud América, así como de sus ideas y aspiraciones. Cada número es una selección de artículos de autores de habla castellana y procuramos que cada republica esté representada por sus mejores exponentes culturales.

84 Delgado, «Concurso literario», 1.

85 «Nuestra Revista en el Ibero Amerikanisches Institut», Ilustración Nariñense, $\mathrm{n}^{\circ}$ 52 (1933): 15. 
Publicamos también las revistas EXPLORATION en inglés, y COPIA en español.

Queremos pedirle a usted señor director, que nos permita traducir y utilizar, eventualmente, los artículos que aparecen en su revista. Por nuestra parte, tendremos mucho gusto en autorizarles para que utilicen el material original de nuestras tres publicaciones.

Si usted acepta este intercambio que redundará, con toda seguridad, en nuestro mutuo beneficio, sírvase poner nuestra dirección en su lista de canjes. Tan pronto como hayamos recibido su contestación iniciaremos el envío regular de SOUTH AMERICAN DIGEST, EXPLORATION Y COPIA ${ }^{86}$.

Las solicitudes de canje reflejan el interés que suscitó la revista en medios internacionales, fruto de lo cual se puede constatar actualmente la existencia de la colección de Ilustración Nariñense en el Instituto Iberoamericano de Berlín, entre 1933 y $1939^{87}$.

Dado que Ilustración incluía en cada número, una profusión de fotos correspondientes a las temáticas tratadas, el lector se informaba de asuntos como los avances en la construcción de la vía férrea, los participantes y logística en la guerra con el Perú -aviones, barcos, lugares y tropas en el conflicto-, visita de políticos al departamento, damas de la sociedad, matrimonios, funerales de personas célebres, miembros de instituciones, poetas y literatos y demás lugares de interés según el tema.

Para los lectores de los pueblos de Nariño o de otras ciudades del país, la publicación se convirtió en un vínculo con la región pues a través de esta podían informarse acerca de los avances logrados por el departamento en materia vial, educativa, industrial, de higiene y salud y progreso de diferentes localidades. La revista destacaba a menudo a intelectuales de

86 J.M. Sheppard, «Intercambio cultural. Atenta comunicación», Ilustración Nariñense, $\mathrm{n}^{\circ} 91$ (1945): 17.

87 Cfr. Catálogo de la Biblioteca del Instituto Iberoamericano de Berlín. http:// iaiweb1.iai.spk-berlin.de/DB=1/LNG=DU/SID=edd8d23f0/CMD?ACT=SRCHA\&IKT $=1016 \&$ SRT $=$ YOP\&TRM=Revista+Ilustracion+Nari\%C3\%B1ense 
la región a través de entrevistas o reseñas sobre la vida de personajes en el campo de la literatura, la historia, el arte o la religión; también relataba en detalle la visita de políticos, incluyendo partes de los discursos y opiniones de estos.

\section{Conclusiones}

Una revista cultural como Ilustración Nariñense nos introduce en los espacios que las élites intelectuales del sur de Colombia utilizaron para difundir sus ideas acerca de las mejores formas de atraer el progreso a la región, en la primera mitad del siglo XX, así como también, permite hacer un diagnóstico del estado del campo intelectual de esta sección del país y contribuye al conocimiento de los proyectos político-culturales que se llevaron a cabo en este periodo.

Este tipo de documentos nos da a conocer cómo actuaron, pensaron y escribieron los hombres y las mujeres - en sus escasas apariciones - acerca de las circunstancias a las que se vieron enfrentados, luchando con los poderes centrales y con condiciones de posibilidad socialmente desiguales, en gran parte debidas al escaso desarrollo de las fuerzas productivas.

Ilustración Nariñense pugnó por un proyecto común como el ferrocarril del Pacífico y el desarrollo vial de Nariño, temas que se convirtieron en ejes que articularon la estructura de la revista; impulsó y difundió los emprendimientos departamentales más destacados, retrató a las élites ciudadanas tanto a través de la prosa como de la fotografía y dio a conocer proyectos y personajes de una región que quería destacarse en el ámbito nacional.

Como experiencia de producción editorial es atípica tanto en el contexto más cercano como a nivel nacional, ya que las revistas culturales generalmente duraban pocos años, en el mejor de los casos. Como registro escrito, proporciona el espacio para conocer la producción de muchos intelectuales de la primera mitad del siglo XX, cuya obra "descansa 
prácticamente en los periódicos" 88 debido al escaso desarrollo de la industria editorial. Como cultura escrita no se debe ver como una cultura impresa destinada exclusivamente a la lectura, pues, como anota Chartier, existe otro tipo de evolución que corresponde a "la creación de una esfera pública de debate, de discusión, de crítica" ${ }^{89}$.

Conocer lo que significó el proyecto editorial de la revista permite tener un mejor conocimiento acerca del pasado reciente y una visión más lúcida sobre el tiempo actual que permita revisar los diagnósticos acerca del presente. La búsqueda del progreso, que había logrado seducir no solo a la clase política de Nariño sino a la mayoría de los sectores de la población, ¿qué lecciones le dejó a los pastusos y nariñenses sobre el fracaso que constituyó el Ferrocarril del Pacífico? Es posible que, como colectivo no haya procesado la experiencia y se mantenga en el sustrato cultural como una frustración más, añadida a situaciones históricas de desencaje con respecto al resto del país, sin tener en cuenta que el desarrollo vial debe ir aparejado al mejoramiento en los sistemas productivos.

Ilustración Nariñense puede registrarse como "una fuente histórica significativa"90 que aportó luces acerca de las formas como Pasto y Nariño escribieron su propia memoria en la primera mitad del siglo XX.

\section{Fuentes Documentales}

Revista Ilustración Nariñense, Pasto, 1924 a 1955. n 1-120.

\section{Bibliografía}

Acevedo Carmona, Darío. «Prensa y confrontación política en Colombia 1930-1950». En Medios y nación. Historia de los

88 Roger Chartier, Cultura escrita, 187.

89 Roger Chartier, Cultura escrita, 86.

90 Fernanda Beigel, Las revistas culturales, 107. 
medios de comunicación en Colombia. VII Cátedra Anual de Historia Ernesto Restrepo Tirado. Bogotá: Ministerio de Cultura, Aguilar, 2003.

Acevedo Tarazona, Álvaro y John Jaime Correa Ramírez. «Empresa, civilización y política: representaciones sobre el oficio periodístico en El Diario de Pereira y Vanguardia Liberal de Bucaramanga durante la República Liberal», Revista de Historia Regional y Local HistoReLo 5, nº 9 (2013): 208-242. Acceso el 3 de abril de 2016, http://www.revistas.unal.edu.co/ index.php/historelo/article/view/36607

Álvarez Hoyos, María Teresa. Élites intelectuales en el sur de Colombia. Pasto 1904-1930. Una generación decisiva. Pasto: Editorial Universidad de Nariño, 2007.

Beigel, Fernanda. «Las revistas culturales como documentos de la historia latinoamericana». Utopía y Praxis latinoamericana 8, n 20 (2003): 105-115. Acceso el 22 de octubre de 2015, https:// www.academia.edu/6342158/Las_revistas_culturales_como_ documentos_de_la_historia_latinoamericana_Fernanda_ Beigel_

Benjamín, Walter. Libro de los Pasajes. Editado por Rolf Tiedemann. Madrid: Ediciones Akal, 2005.

Betancourt, Alexander. «Región y Nación: dos escalas sobre un tema de estudio». Relaciones (Zamora) 33, $\mathrm{n}^{\circ} 130$ (2012): 25-68. Acceso el 20 de marzo de 2016, http://www.scielo.org.mx/scielo. php?script=sci_arttext\&pid=S0185-39292012000200003

Castro-Gómez, Santiago. Tejidos Oníricos. Movilidad, capitalismo y biopolítica en Bogotá (1910-1930). Bogotá: Editorial Pontificia Universidad Javeriana, 2009.

Chartier, Roger. Cultura escrita, literatura e historia. México: Fondo de Cultura Económica, 2003.

De la Fuente, José Alberto «Vanguardias literarias ¿una estética que nos sigue interpelando?». Literatura y Lingüística, $\mathrm{n}^{\circ}$ 16 (2005): 31-50. Disponible en: http://www.scielo.cl/scielo. php?pid=S0716-58112005000100003\&script=sci_arttext $\quad(14$ abril 2015). 
Figueroa Santacruz, Edgar Ricardo. «La Fotografía en Pasto» (Primera Parte). En Manual Historia de Pasto Tomo XVI. Pasto: Academia Nariñense de Historia, 2015.

Loaiza Cano, Gilberto. "La búsqueda de autonomía del campo literario. El Mosaico, Bogotá, 1858-1872». Boletín Cultural y bibliográfico 41, nº 67 (2004): 2-19.

López Lenci, Yazmín. «La creación de la nación peruana en las revistas culturales del Cusco (1910-1930)». Revista Iberoamericana LXX, n 208-209 (2004): 697-720.

Martín Barbero, Jesús. «Colombia: ausencia de relato y desubicaciones de lo nacional». En Imaginarios de nación. Pensar en medio de la tormenta, coordinado por Jesús Martín Barbero. Bogotá: Ministerio de Cultura, Cuadernos de Nación, 2001.

Melo, Jorge Orlando. «La libertad de prensa en Colombia: pasado y perspectivas actuales». En Fortalezas de Colombia, editado por Fernando Cepeda Ulloa (Bogotá: Ariel y Banco Interamericano de Desarrollo) 2004.

Ovares, Flora. «Crónicas de lo efímero: un siglo de revistas culturales y literarias costarricenses». Revista Iberoamericana LXX, $\mathrm{n}^{\circ}$ 208-209 (2004): 1003 - 1013.

Pita González, Alexandra, Grillo, María del Carmen. «Una propuesta de análisis para el estudio de revistas culturales». Revista Latinoamericana de Metodología de las Ciencias Sociales 5, $\mathrm{n}^{\circ} 1$ (2015) Acceso el 1 de noviembre de 2015, http://www. relmecs.fahce.unlp.edu.ar/article/view/relmecsv05n01a06

Restrepo, Alonso. Apuntes, notas y algunos comentarios del Médico de la Comisión de Cultura Aldeana que visitó el Departamento de Nariño. Medellín: Imprenta Oficial, 1935.

Sarlo, Beatriz. Una modernidad periférica: Buenos Aires 1920 y 1930. Buenos Aires: Ediciones Nueva Visión, 1988.

Schwartz, Jorge. Las vanguardias latinoamericanas. Textos programáticos y críticos. México: FCE, 2002.

Vallejo Mejía, Maryluz. «Los genes de la prensa nonagenaria y centenaria». En Un papel a toda prueba. 223 años de prensa 
diaria en Colombia. Bogotá: Andiarios, Biblioteca Luis Ángel Arango, 2012. Acceso el 22 de marzo de 2016, http://www. banrepcultural.org/un-papel-a-toda-prueba/los-genes-de-laprensa

Verdugo, Jorge. Sobre el Canon y la Canonización de la Narrativa en Nariño en el siglo XX. Pasto: Editorial Universidad de Nariño, 2004.

Zarama, Rosa Isabel. «Historia del Ferrocarril de Nariño». Tendencias 17, $\mathrm{n}^{\circ} 1$ (2016): 87-103.

\section{Citar este artículo:}

Álvarez Hoyos, María Teresa. «Ilustración Nariñense, la revista cultural del sur de Colombia. 1924-1955». Historia Y MEMORIA, $\mathrm{n}^{\circ} 13$ (2016): 257-297. DOI: http://dx.doi. org/10.19053/20275137.5206 